\title{
Effect of Entrepreneurship Education, Creativity, and Self Efficacy on Entrepreneurship Interest in Vocational Students
}

\author{
Silvia Roza1, Bustari Muchtar ${ }^{2}$, Syamwil $^{3}$ \\ ${ }^{1}$ University of Padang, Padang, Indonesia, $\triangle$ silviaroza61gmail.com \\ ${ }^{2}$ University of Padang, Padang, Indonesia, $\bowtie$ bustarimuchtar@yahoo.com \\ ${ }^{3}$ University of Padang, Padang, Indonesia, $\bowtie$ syamwil@fe.unp.ac.id
}

\begin{abstract}
This study aims to determine the extent of the influence of entrepreneurship education, creativity, and self-efficacy on the interests of entrepreneurship in vocational students in Padang Pariaman Regency. The type of research is expose factor. The total population in this study was 2097 people with technique of proportional random sampling from 95 students. Data collected by descriptive analysis and prerequisite test analysis. The results of the descriptive analysis are in the quantitative good category is equal to 34,645 and the partial way of Entrepreneurship, Creativity and education Self Efficacy has a significant positive effect on the interest in entrepreneurship of SMK students in Padang Pariaman Regency. The results of simultaneous data analysis on entrepreneurship education, creativity and self efficacy show a figure of 0.532 or $53.2 \%$.
\end{abstract}

Keywords: Entrepreneurship education, creativity, self efficacy and interest in entrepreneurship

\section{Introduction}

The increasingly high unemployment rate has become a hot topic among the public. This arises because of the lack of available jobs. Unemployment arises from educated and uneducated circles. The government again moved the interest in entrepreneurship, namely by entering entrepreneurship subjects both in lectures and secondary schools. In accordance with the government's expectations, namely by developing entrepreneurial interests will improve the economy of the community. This is supported by the opinion of Brownhilder (2014) stating that entrepreneurship is the best solution to reduce unemployment, especially among young people and more unemployment that occurs among educated people who are unable to find work. But in reality, it was not as expected.

The interest in one's entrepreneurship is influenced by many factors, including entrepreneurship education, creativity, self efficacy, capital, business opportunities etc ... This is in line with the opinion of Fatrika, (2009) stating the factors that influence interest are: characteristics (gender and age), environment (family environment, educational environment, and community environment), personality (appreciation, understanding / aggressiveness, risk taking, need for achievement and independence, self evaluation and more self-confidence), and motives for entrepreneurship (working and creative ideas distribution )

Vocational High School is one of the places to realize the hopes of the government, namely by giving birth to entrepreneurs, who will later create their own jobs without having to wait for jobs from the government. This is in accordance with the purpose of the establishment of Vocational School, namely to create graduates who can be directly deployed in the field of work and able to open their own employment. But this goal cannot be achieved as it is. Most of the graduates of Vocational School if they are in the field of work are used as laborers and are not in accordance with the skills that they have ever had. Based on observations made, the interview with one of the principals of Sintuk to Gadang 1 SMKN states that out of 229 students who completed their study in 2017, 52\% continued their studies, 45\% worked in the business and industrial world and 3\% self-employed "(Principal source SMK 1 SintuktobohGadang). From the explanation above we can know the low interest in student entrepreneurship.

This condition requires a solution, one of which is through education. This education can be obtained by someone through school or lectures. With the existence of the school becomes a vehicle 
for someone to get education, as expected with the education they have can foster an interest in one's entrepreneurship. This is in accordance with the opinion of Van der Sluis et al. (2007) stating that entrepreneurship education plays an important role in fostering interest in entrepreneurship developed in school age. With the existence of entrepreneurship education will foster the skills they have. In America, a school applies its entrepreneurship education by involving students in small business ventures such as the business of buying and selling shares managed by lecturers and students as marketers (Oosterbeek et.al:2010).

But in reality, what happens in the field of education is only limited to education to gain knowledge, without further application. The results of interviews conducted with several students who explained that they were more inclined to work with other sectors than they would develop the knowledge, skills and attitudes obtained when undergoing education. From this explanation we can see that the lack of applied entrepreneurship education that students get, and not the development of creativity students in producing products. They should be able to create their own business from education and creativity they have.

In addition, students should also be creative in seeing opportunities with the world market. Thus, if they can more creatively seize opportunities, they are able to create new products that are in line with the market. However, in reality the field is not as desired. As the vocational school students should be more skilled and creative in producing what actually happens otherwise. They are more inclined to accept the idea of the teacher than to be creative. This is in accordance with the opinion of Yang and Chiayu (2013) Creativity is an entrepreneurial spirit that employs ideas to produce a new business that gives birth to new products and services that can be used on the market.). In line with that Pretorius, Millard, and. Kruger (2005) states that creativity is the main factor and the starting point for someone to create a new business and the key to achieving success.

From the results of interviews with students, information was also obtained that they did not have confidence in themselves. As their presentation, "if we are self-employed, if successful it is good, but if it fails, it will certainly be a waste of money and it is better to do real work". From what they say we can also conclude that there is no confidence in students in entrepreneurship. A person's beliefs should also be a driver of interest in entrepreneurship. This is in line with the opinion of Bernstein \&Carayannis, (2012) stating that the interest in entrepreneurship depends on self-efficacy possessed by an entrepreneur. In addition, Djoko (2015) stated that self efficacy can influence someone's interest in something extraordinary in opening a business.

Koloba, Dhurup And Radebe (2015) stated that Self-Efficacy is a belief that someone has to work and relate to the environment in order to be able to perform tasks in different ways. From some of the descriptions above, it can be seen that self-efficacy is the driver of someone's interest in entrepreneurship. With the existence of high self-efficacy, it will give confidence to a person in decision making. In accordance with the above problems, this article appeared to analyze the effect of entrepreneurship education, creativity and self-efficacy on the interests of entrepreneurship in vocational students in the Padang Pariaman district.

\section{Methods}

Research is research survey. This research was conducted at the Padang Pariaman Vocational School, with a population of 2097 students. The sampling technique in this study was proportional random sampling totaling 95 people. The data collection techniques in this study were using questionnaires / questionnaires. Obtained the results of the fourth questionnaire test variables distributed to 30 respondents had a value of $\mathrm{r}$ approaching 1, which means that the four variable questionnaires in this article can be used for different respondents. The data analysis method used is descriptive analysis and prerequisite test analysis, the analysis of this prerequisite test uses the classic assumption test including normality test, homogeneity test and multicollinear test, using analysis tool Statistical Package for The Social Science (SPSS). 


\section{Results and Discussion}

Descriptive results showed good categories, as shown in the following table:

Table 1 Distribution of Variables

\begin{tabular}{llll}
\hline Variable & Mean & TCR & Category \\
\hline Entrepreneurship Education & 3.59 & 71.81 & Good \\
\hline Creativity & 3.19 & 65.11 & Good \\
\hline Self Efficacy & 3.33 & 66.62 & Good \\
\hline Entrepreneurial Interest & 3.34 & 66.75 & Good \\
\hline Total & 13.45 & 279.29 & Good \\
\hline Average & 3.36 & 69.82 & Good \\
\hline
\end{tabular}

From table 1 describes data about the mean of the four variables which are equal to 3.36 with TCR 69.82 in the good category. It can be concluded that the interest in student entrepreneurship is good.

From the results of the test results, the value of $f$ arithmetic is 34,645 with a sig value of 0,000 , as shown in the following table:

Tabel 2 F test

\begin{tabular}{|c|c|c|c|c|c|c|}
\hline \multicolumn{7}{|c|}{ ANOVA $^{b}$} \\
\hline \multicolumn{2}{|c|}{ Model } & \multirow{2}{*}{$\begin{array}{r}\text { Sum of Squares } \\
5061.511\end{array}$} & \multirow{2}{*}{$\begin{array}{r}\text { Df } \\
3\end{array}$} & \multirow{2}{*}{$\begin{array}{r}\text { Mean Square } \\
1687.170\end{array}$} & \multirow{2}{*}{$\frac{\mathbf{F}}{34.519}$} & \multirow{2}{*}{$\begin{array}{l}\text { Sig. } \\
.000^{\mathrm{a}}\end{array}$} \\
\hline 1 & Regression & & & & & \\
\hline & Residual & 4447.795 & 91 & 48.877 & & \\
\hline & Total & 9509.305 & 94 & & & \\
\hline \multicolumn{7}{|c|}{ a. Predictors: (Constant), Self Efficacy, Creativity, Entrepreneurship Education } \\
\hline \multicolumn{7}{|c|}{ b. Dependent Variable: Entrepreneurship } \\
\hline Intere & & & & & & \\
\hline
\end{tabular}

From table 2 , it can be seen that the sig value is $<0.05$, so it can be concluded that entrepreneurship education, creativity and self-efficacy jointly influence the interest of student entrepreneurship. This means that the higher entrepreneurship education, creativity and self efficacy will increase the interest in student entrepreneurship. This is supported by Chomzana and sitiHamidah (2014) research in his research entitled "The Effect of Self-Efficacy, Family Environment, and School Environment on Interest in Entrepreneurship for Secondary Students in Catering" states that there are influences of selfefficacy, family environment, and school environment both individually and jointly with interest in entrepreneurship. Furthermore, also supported by Sifa Farida in her research in 2016 entitled "The effect of entrepreneurship education, family environment, and self efficacy on the interests of entrepreneurship in vocational students accounting expertise program" concluded that there was a positive and significant influence of entrepreneurship education on interest in entrepreneurship $6.05 \%$. Then proceed to the $t$ test.

The results of the simple regression analysis test, as shown in the table 3 below, From table 3 the simple regression coefficient results can be explained so that the equation $\mathrm{Y}=10,915+0,133 \mathrm{X} 1+$ $0,347 \mathrm{X} 2+1,077 \mathrm{X} 3$. Based on these equations, it can be concluded when entrepreneurship education is 0 then the interest in student entrepreneurship is 10,915 , so too then with creativity and self efficacy. Furthermore, the value contained in the regression criteria for the value of $\mathrm{X} 1$ is 0.133 , illustrating that every $1 \%$ increase in entrepreneurship education will increase $13.3 \%$ of entrepreneurial interest. Next valueX2 amounted to 0.347 significantly every $1 \%$ increase creativity will increase $34.7 \%$ interest in entrepreneurship and X3 at 1,077 means each 1\% increase in self-efficacy will affect $10,77 \%$ interest in entrepreneurship students. 
Table 3 T test

\begin{tabular}{|c|c|c|c|c|c|}
\hline \multicolumn{6}{|c|}{ Coefficients $^{a}$} \\
\hline \multirow[t]{2}{*}{ Model } & \multicolumn{2}{|c|}{$\begin{array}{l}\text { Unstandardized } \\
\text { Coefficients }\end{array}$} & \multirow{2}{*}{$\begin{array}{c}\begin{array}{c}\text { Standardized } \\
\text { Coefficients }\end{array} \\
\text { Beta }\end{array}$} & \multirow[t]{2}{*}{$\mathbf{t}$} & \multirow[t]{2}{*}{ Sig. } \\
\hline & B & Std. Error & & & \\
\hline (Constant) & 10915 & 9228 & & -1.183 & 0.24 \\
\hline Entrepreneurs & & & & & \\
\hline hip education & 0.133 & 0.077 & 0.124 & 2.603 & 0.087 \\
\hline Creativity & 0.347 & 0.066 & 0.383 & 5.292 & 0.455 \\
\hline Self Efficacy & 1.077 & 0.115 & 0.679 & 9.338 & 0.276 \\
\hline $\begin{array}{l}\text { a. Dependent Var } \\
\text { Entrepreneurship }\end{array}$ & Interest & & & & \\
\hline
\end{tabular}

In addition, from the table data above, it can also be seen from the results of hypothesis testing, namely:

The Effect of Entrepreneurship Education on Entrepreneurial Interest in Vocational School Students in Padang Pariaman Regency.

From the table above we can see the value of $t$ arithmetic is 2.603 with sig 0.087 . This means that the value of sig $\mathrm{t}>0.05(0.087>0.05)$ then $\mathrm{H}_{0}$ is rejected. So, it can be concluded that there is a positive and significant effect of entrepreneurship education on the interest in entrepreneurship in students of SMK Padang Pariaman Regency. This means that the higher the entrepreneurship education of students, the higher the entrepreneurship motivation of the students of the Vocational School in Padang Pariaman Regency. This is supported by the research of Retno and Trisnadi (2012) in his research entitled "The Influence of Entrepreneurship Education on the Interest of Student Entrepreneurship in StieMdp, StmikMdp, and StieMusi" stating that entrepreneurship education has a significant

The Effect on Entrepreneurial Interest. Padang Pariaman Vocational School.

The value of $t$ count for the creativity variable is 5.292 with sig 0.455 . This means that the sig $t$ value counts more than the $t$ table, which is sig $t>0.05$ (0.456>0.05), according to the predetermined hypothesis, so there is a positive and significant influence of creativity on the interest in entrepreneurship in the students of SMK regency Padang Pariaman. This means that if the creativity of students increases, the interest in entrepreneurship in vocational high school (SMK) Pariaman Regency students increases. Supported by Sugiarto's research, et al. (2015) in his research entitled "The relationship between entrepreneurship creativity and automotive entrepreneurship interest in vocational students" argues that there is a relationship between entrepreneurial creativity and interest in entrepreneurship by 0.335

\section{The Effect of Self Efficacy on Entrepreneurship Interest in Padang Pariaman Vocational School} Students.

Known value of $t$ for self efficacy variable of 9.338 with sig 0,276 , which means that in accordance with the rules of decision-making $\mathrm{H}_{0}$ accepted if sig $\mathrm{t}>0.05, \mathrm{H}_{0}$ is rejected if sig $\mathrm{t}<0.05$. Sig $\mathrm{t}>0.05$ $(0.276>0.05)$ then $\mathrm{H}_{0}$ is rejected. So, it can be concluded that there is a positive and significant effect of self-efficacy on the interest in entrepreneurship in students of SMK Padang Pariaman Regency. This means that the higher the self-efficacy student's, the higher the interest in entrepreneurship in SMK Pariaman Regency students. The same results also presented by Iro-Idoro, CB \&Iro-Idoro, EU (2015) in his research in Nigeria found that self efficacy has a significant effect on the interest of student entrepreneurship in Nigeria

The determination test is conducted to determine how much influence the independent variable has on the dependent variable. as shown below: 
Table 4 Analysis of determination

\begin{tabular}{lrrrc}
\hline \multicolumn{5}{c}{ Model Summary } \\
\hline Model & R & R Square & $\begin{array}{l}\text { Adjusted } \\
\text { R Square }\end{array}$ & $\begin{array}{c}\text { Std. Error of } \\
\text { the Estimate }\end{array}$ \\
\hline 1 & $.730^{\mathrm{A}}$ & 0532 & 0518 & 6.59454 \\
\hline \multicolumn{2}{c}{ a. Predictors: (Constant), Self Efficacy, entrepreneurship education, Creativity } \\
\hline
\end{tabular}

From Table 4 above, we can know the test results of multiple regression showed that the coefficient of determination $\left(\mathrm{R}^{2}\right)$ of 0.532 or $53.2 \%$. This means that $53.3 \%$ of interest in entrepreneurship is influenced by entrepreneurship education, creativity, and self-efficacy. While the remaining $46.8 \%$ is influenced by other variables not examined in this study.

Based on the test results obtained results that show entrepreneurship education has a significant effect on the interest in entrepreneurship of Vocational students in Padang Pariaman Regency. The results of this study in accordance with the results of a study conducted by Sifa Farida in 2016 in his research entitled "The effect of entrepreneurship education, family environment, and self efficacy on the interests of entrepreneurship in vocational students accounting expertise program" concluded that there was a positive and significant influence on entrepreneurship education on interest entrepreneurship $6.05 \%$.

Besides that, Afolabi. At.all (2017) in his research entitled "Effect of Entrepreneurship Education on Self-Employment Initiatives among Nigerian Science and technology to start a business without much or reducing stress) $\mathcal{E}$ Technology Students student entrepreneurship education can stimulate science and technology students to start business ventures without much or less stress. (entrepreneurship education can stimulate science students.

This is also supported by the opinions of Retno and Trisnadi (2012) in his research entitled "The Influence of Entrepreneurship Education on Student Entrepreneurship Interests in StieMdp, StmikMdp, and StieMusi" stating that entrepreneurial education has a significant effect on interest in entrepreneurship

\section{Conclusion}

From the results of the discussion it can be concluded that entrepreneurship education, creativity and self-efficacy have a positive effect on students' interest in entrepreneurship. This, means that entrepreneurship education, creativity and self-efficacy simultaneously have a significant effect on the interest in entrepreneurship. hence the higher interest in entrepreneurship of Vocational students in Padang Pariaman Regency

\section{References}

Afolabi.at.all. (2017). Effect of Entrepreneurship Education on Self-Employment Initiatives among Nigerian Science \& Technology Students.Journal of Education and Practicewww.iiste.org ISSN 2222-1735 Paper ISSN 2222-288X Online Vol. 8, 15, 2017

Alma, Buchari. (2011). "Entrepreneurship". Bandung: Alfabeta.

Bandura, A. (1997).Self Eficaccy: The Exercise Of Control. New York.

Bernstein, AT \&Carayannis, EG, (2012). Exploring the Value Proposition of the Undergraduate Entrepreneurship Major and Elective Based on Student Self-Efficacy and Outcome Expectations. Lournal of Knowledge Management, Economics and Information Technology, pp.265-279

Chia Chen-Ching. (2016). Influence of Creativity and Social Capital on the Entrepreneurial Intention of Tourism Students. Lournal of Entrepreneurship, Management and Innovation. Volume 12, 2016 Issue 2.

Dikti. 2009. Guide to Student Entrepreneurship Programs. www.dikti.go.id.

Hamid Darmadi. (2011). Educational Research Methods. Bandung: Alfabeta

Hapsah, Rifqi and Siti Ina Safira (2013).Relationship between Self efficacy and Creativity with Interest in Entrepreneurship.Journal of Character Volume 02 Number 02 of 2013 
Iro-Idoro, CB \&Iro-Idoro, EU Self-Efficacy as correlating the entrepreneurial intention of tertiary institution students in Ogun State, Nigeria. Self, 5 (2) (2015)

Koloba. HA, M. Dhurup and P. Radebe. The effects of self-efficacy on entrepreneurial inclinations: Evidence from sport management students in the Southern Gauteng region of South Africa. African Journal for Physical, Health Education, Recreation and Dance (AJPHERD) November (2015)(Supplement 1), pp. 65-79.

Kusumajanto, Dwi Djoko. (2015). The Role of Entrepreneurship Education and Self Efficacy in Shaping Student Interest in Doing Entrepreneurship. European Journal of Business and Management, Vol. 7 No. 28

M. Pretorius, SM Millard, and ME Kruger, "Creativity, innovation and implementation: Management experience, venture size, life cycle stage, race and gender as moderators," South African Lournal of Business Management, vol. 36, no. 4, pp. 55-68, (2005).

Marini, Chomzana Kinta. (2014). The Effect of Self-Efficacy, Family Environment, and School Environment on Student Entrepreneurship Interest in Catering Services. Lournal of Vocational Education, Vol. 4 Number 2. Page 195

Mostopha, MuchammadArif. (2014). The influence of entrepreneurial knowledge, self efficacy, and entrepreneurial character on the interest in entrepreneurship in class XI students of SMK Negeri 1 Depok, Sleman Regency. Yogyakarta.

Oosterbeek, et.al. (2010). The impact of entrepreneurship education on entrepreneurship skills and motivation. European Economic Review journal homepage: www.elsevier.com/locateleer

Peng, Z., Lu, G. \& Kang, H. Entrepreneurial intentions and its influencing factors: A survey of the University Students in Xi'an China. Creative Education, 3, 95-100 (2012)

Retno Budi Lestari and TrisnandiWijaya. (2012). Effect of Entrepreneurship Education on Interest in Student Entrepreneurship in STIE MDP, STMIK MDP, and STIE MUSI. Journal.STIE MDP.

Riduwan. (2010). Easy Study Learning. Bandung: Alfabeta

Shinnar, RS, Hsu, DK \& Powell, BC Self-efficacy, entrepreneurial intentions, and gender: Assessing the longitudinally impact of entrepreneurship education, The International Journal of Management Education, 12 (3), 561-570, (2014)

Singer, Kurts. (1987). Fostering Learning Desires in Schools. Bandung: Youth RosdaKarya.

SoekidjoNotoatmodjo. (2003). Health Education and Behavior. Jakarta: RinekaCipta.

Souitaris, V., Zerbinati, S. \& Al-Laham, A. Do entrepreneurship programs raise entrepreneurial intention of science and engineering students? The effect of learning, inspiration and resources.Journal of Business Venturing, 22 (4), 566-591, (2007)

UN Saraih, Ain Zuraini Zin Aris, Suhana Abdul Mutalib, TunkuSalhaTunku Ahmad, Sharmini Abdullah and M. HarithAmlus. The Influence of Self-Efficacy on Entrepreneurial Intention among StudeEngineeringntsMATEC Web of Conferences 150,05 051 (2018) https://doi.org/10.1051/matecconf/201815005051 MUCET 2017 